\title{
FORMULATION AND EVALUATION OF SOME HIGH FIBER PRODUCTS
}

\author{
(Received: 26. 2. 2014)
}

\author{
By \\ S. A. Arafa, Kh. M. Nematalla and E. M. Khalil \\ Special Food and Nutrition Department, Food Technology Research Institute, \\ Agricultural Research Center, Giza, Egypt
}

\begin{abstract}
The growing consumer demand for food with good nutritional and sensory quality has called for research to develop products using untraditional materials. Rice bran (by-product of rice milling industry) could be utilized as a source of dietary fiber. Wheat flours (82\% and $72 \%$ extractions) were substituted with different levels of rice bran, i.e., 5\%, 10\% and 15\% to produce pan bread and salted biscuits. The chemical composition of raw materials and different substituted bakery products, physical properties, sensory characteristics, mineral contents, total phenolic compounds, antioxidant activity, nutritional and biological values of these bakery products were evaluated.

The obtained results indicated that rice bran could be considered as a good source of crude fiber and total dietary fiber. Total dietary fiber increased by 1.1, 1.4 and 1.6 folds for pan bread samples substituted with rice bran at levels of 5\%,10\% and $15 \%$, respectively, and the increment percentages ranged from $50.31 \%$ to $135.49 \%$ for salted biscuits samples substituted with rice bran compared with control samples. Chemical composition, physical properties and sensory evaluation of both pan bread and salted biscuits samples revealed that, the level of $10 \%$ rice bran was found to be the best replacement level without any adverse effects on physical and sensory attributes of bakery products. The presence of rice bran in substituted pan bread and salted biscuits caused an increase in all mineral contents. One serving of pan bread and salted biscuits equivalent to $100 \mathrm{~g}$ containing $10 \%$ rice bran can be considered nutritious in terms of total dietary fiber, calorific value, phenolic contents and showed an antioxidant activity. Amino acids scores, protein efficiency ratio and biological value of bakery products were also improved by substitution with rice bran.

It can be recommended that using composite flour should be encouraged to make economic use of local raw materials and to produce high quality food products for people with special health conditions such as diabetics and elevated serum cholesterol subjects.
\end{abstract}

Key words: biological value, nutritive value, pan bread, rice bran,total dietary fiber, salted biscuits

\section{INTRODUCTION}

Dietary fiber intake could be easily increased by selecting food naturally high in fiber. Baked products with various high fiber additives such as biscuits, cookies, cakes and pan cake mixes have been produced to satisfy consumer demands for high fiber content in foods without sacrificing sensory quality. Egypt has been the largest rice producer in the Middle East region, averaging rough rice production of 6.812 million tons and milled rice production of 4.850 million tons in 2013, which is expected to reach in 2014 about 7.536 and 5.200 million tons for rough and milled rice productions, respectively (USDA, 2013).
Rice bran, the secondary product of rice milling industry, which contained a germ and an outer layer could be considered a rich source for nutritional components such as dietary fibers, phytic acids, vitamins $\mathrm{B}$ and $\mathrm{E}, \boldsymbol{\gamma}$-oryzanol and gamma amino butyric acid (GABA) compared to the ordinary rice grains. These bio-functional components were found to be in the germ and bran layers. Defatted rice bran contained $13.89 \%$ crude protein, $1.92 \%$ ether extract, $10.13 \%$ ash, $12.43 \%$ moisture, $6.03 \%$ crude fiber and $55.60 \%$ carbohydrates (Champagne et al., 2004 and Jiamyangyuen et al., 2005).

Dietary fiber has been shown to have important health implications in the prevention risk of chronic diseases such as cancer, 
cardiovascular diseases and diabetes. Dietary fiber has the ability to bind with bile acids and prevents its re-absorption in the liver, thus inhibit cholesterol synthesis. Dietary fiber's viscous and fibrous structure could control the release of glucose with time in the blood, thus helping in the proper control and management of diabetes and obesity (Brownlee, 2011 and Phillips, 2011).

Among different value added food systems, baked foods, i.e., bread, cookies, biscuits and cakes have been consumed worldwide relatively on large scale and provide an excellent opportunity to incorporate food-grade fractions from grains, legumes or other non-traditional food sources (Siddiq et al.,2009).

This study was designed to produce healthy pan bread and salted biscuits substituted with rice bran as a high fiber source at different replacement levels of wheat flour, i.e., $5 \%, 10 \%$ and $15 \%$, respectively, and evaluate the chemical composition, physical properties and sensory attributes of these products to assess the best level of rice bran addition. Antioxidant activity, phenolic compounds, nutritional and biological values of these products were also evaluated.

\section{MATERIALS AND METHODS \\ 2.1. MATERIALS}

Stabilized defatted rice bran (Oryza sativa, variety Sakha 101) was obtained from Delta Company for Rice Milling, New Damietta, Damietta Governorate, Egypt. Wheat flour (Triticum vulgare) $82 \%$ and $72 \%$ extractions, sugar, fats, salt, dry yeast, milk powder and improvers were bought from local market, Giza, Egypt. All chemicals and reagents used were purchased from Sigma Chemical Company (St. Louis, MO, USA).

\subsection{METHODS}

\subsubsection{Preparation of pan bread}

Wheat flour (82\% extraction) replaced with different levels of rice bran $(5 \%, 10 \%$ and $15 \%)$ was used for the preparation of pan bread samples. The conventional straight dough process for pan bread was performed according to the routine method of the Egyptian Baking Technology Center, Giza, Egypt. The ingredients used included $100 \mathrm{~g}$ wheat flour, $5 \mathrm{~g}$ sugar, $5 \mathrm{~g}$ margarine, $1 \mathrm{~g}$ salt, $1.5 \mathrm{~g}$ active dry yeast, $2 \mathrm{~g}$ milk powder and $1 \mathrm{~g}$ improvers. The ingredients were mechanically mixed for 12 min., then the dough was left to ferment for 2 hrs, then the dough was divided into equal parts of about $165 \mathrm{~g}$ pieces, rested for $2 \mathrm{hrs}$ for final fermentation, then made into loaves. The loaves were baked at $220^{\circ} \mathrm{C}$ for $15 \mathrm{~min}$. in the baker house, all loaves were packaged in polyethylene bags after cooling and kept for analysis.

\subsubsection{Preparation of salted biscuits}

Wheat flour (72\% extraction) replaced with different levels of rice bran $(5 \%, 10 \%$ and $15 \%)$ was used for the preparation of salted biscuit samples. Biscuit samples were prepared according to the method described in A.A.C.C. (2002). The ingredients used included $100 \mathrm{~g}$ wheat flour, $15 \mathrm{~g}$ margarine, $0.5 \mathrm{~g}$ baking powder, $5 \mathrm{~g}$ salt, $1 \mathrm{~g}$ vanillin and $30 \mathrm{ml}$ water. The dough was allowed to ferment for about $3 \mathrm{hr}$ at $30^{\circ} \mathrm{C}$. Biscuits were baked in continuous band oven at $230^{\circ} \mathrm{C}$ for 10 to $15 \mathrm{~min}$. Biscuit samples were packaged in polyethylene bags after cooling and kept for analysis.

\subsubsection{Chemical analysis of raw materials, pan bread and salted biscuit samples}

Pan bread and salted biscuit samples were dried in an oven for $24 \mathrm{hr}$ at $60^{\circ} \mathrm{C}$ and ground to pass through a 20 mesh sieve, stored in air tight containers and kept in a freezer until analysis. Wheat flours ( $82 \%$ and $72 \%$ extractions), rice bran, pan bread and salted biscuits were analyzed for moisture, crude protein, crude fiber, ether extract and crude ash using the methods described in A.O.A.C. (2005). Total carbohydrates were calculated by difference. Total dietary fiber, soluble and insoluble dietary fiber contents were determined according to the method described by Asp et al. (1983). Mineral contents were determined in the samples using a Perkin Elmer Optima 2100 DV model (Shalton, USA) coupled with plasma spectrometer according to Barnes (1997). Total phenolic compounds were determined according to Singelton et al. (1999) using gallic acid as standard and the results expressed as mg gallic acid equivalent/100g. Total antioxidant activity of the tested samples against stable 2,2-diphenyl1-picrylhydrazyl (DPPH) assay was performed according to the method described by Karioti et al. (2004). Amino acids were determined using a high performance analyzer system (automatic amino acid analyzer), 7300 Beckman, HPLC according to the method described by Becker $e t$ al. (1981). Tryptophan was chemically determined by the method of Miller (1967).

\subsubsection{Physical properties of pan bread and salted biscuits}

Weight of the tested samples was recorded by using sensitive balance $(0.1 \mathrm{~g})$. Volumes were 
measured using rapeseed displacement method and specific volumes were calculated using the following equation: Specific volume $\left(\mathrm{cm}^{3} / \mathrm{g}\right)=$ volume $\left(\mathrm{cm}^{3}\right)$ / weight (g). Density was calculated using the following equation: Density $\left(\mathrm{g} / \mathrm{cm}^{3}\right)=$ weight $(\mathrm{g}) /$ volume $\left(\mathrm{cm}^{3}\right)$. All physical properties were measured according to the methods of A.A.C.C. (2002).

\subsubsection{Nutritive value of pan bread and salted} biscuits

The nutritive value of $100 \mathrm{~g}$ tested samples as a source of dietary fiber was calculated considering the average Dietary Reference Intake (\%DRI) for adults of dietary fiber as $25 \mathrm{~g}$ dietary fiber/day/2000K.cal diet (Federal Register, 1993). Pan bread and salted biscuit samples could be classified as dietary fiber according to the categories proposed by Philippi (2008) to: food source (contains more than 5\% of DRI of dietary fiber in a usual serving), good food source (contains between $10 \%$ and $20 \%$ of the DRI in a usual serving) and excellent food source (contains more than $20 \%$ of the DRI in a usual serving). The calorific value was calculated using the following equation: Calorific value $=(\%$ carbohydrate $\times 4.1)+(\%$ protein $\times 4.1)+(\%$ fat $\times 9.1)$, according to James (1995).

\subsubsection{Biological evaluation of pan bread and salted biscuits \\ 1. Amino acid score}

The chemical score of the protein was calculated by expressing the amount of each essential amino acid of the tested material as percentage of the content of the same individual amino acid in reference protein of $\mathrm{FAO} / \mathrm{WHO}$ pattern (FAO/WHO, 2008).

\section{Amino acid score =}

$\mathrm{g}$ of amino acid in tested material $\times 100$ $\mathrm{g}$ of amino acid in the $\mathrm{FAO} / \mathrm{WHO}$ refernce

\section{Protein efficiency ratio (PER)}

PER value was calculated according to the following regression equation proposed by Alsmeyer et al. (1974) as follows: PER $=0.684$ + 0.456 (Leucine) - 0.047 (Proline).

\section{Biological value}

Biological value of the tested samples was calculated according to the equation reported by Mitchell and Block (1946) as follows: Biological value $(\%)=49.4+10.53$ (PER).

\subsubsection{Sensory evaluation of pan bread and salted biscuits}

Sensory evaluation of the tested pan bread and salted biscuit samples was carried out by ten trained panelists from Special Food and Nutrition Department, Food Technology Research Institute, Giza, Egypt. Pan bread samples were evaluated for appearance (10), color of crust (15), color of crumb (15), distribution of crumb (15),taste (15), homaganity (15) and odor (15) according to Meilgaard et al. (2007). Salted biscuit samples were evaluated for appearance (10), color (15), thickness (15), crispiness (15), shrinkage (15), taste (15) and odor (15) according to Smith (1972).

\subsubsection{Statistical analysis}

The standard analysis of variance procedure in a completely randomized design was applied for the present data according to Gomez and Gomez (1984). Least significant difference test (LSD) was done. The level of statistical significance was set at $\mathrm{p}<0.05$.

\section{RESULTS AND DISCUSSION \\ 3.1. Chemical composition of raw materials}

The chemical composition of wheat flours (82\% and $72 \%$ extractions) and rice bran is shown in Table (1). It could be noticed that rice bran contained the highest crude protein, ether extract, crude fiber and ash compared with wheat flours (82\% and $72 \%$ extractions). Total

Table (1): Chemical composition of wheat flours and rice bran (\% dry weight basis).

\begin{tabular}{|l|c|c|c|}
\hline Constituents & $\begin{array}{c}\text { Wheat flour } \\
(\mathbf{8 2 \%} \text { extraction })\end{array}$ & $\begin{array}{c}\text { Wheat flour } \\
(\mathbf{7 2 \%} \text { extraction })\end{array}$ & Rice bran \\
\hline Moisture & $\mathbf{1 2 . 6 3} \pm \mathbf{0 . 1 7}$ & $\mathbf{1 1 . 7 8} \pm \mathbf{0 . 1 3}$ & $\mathbf{9 . 0 2} \pm \mathbf{0 . 6 4}$ \\
\hline Crude protein & $\mathbf{1 2 . 4 9} \pm \mathbf{0 . 1 3}$ & $\mathbf{1 1 . 1 5} \pm \mathbf{0 . 1 0}$ & $\mathbf{1 3 . 8 3} \pm \mathbf{0 . 1 4}$ \\
\hline Ether extract & $\mathbf{0 . 9 8} \pm \mathbf{0 . 2 0}$ & $\mathbf{1 . 3 8} \pm \mathbf{0 . 3 0}$ & $\mathbf{1 . 4 1 \pm 0 . 2 7}$ \\
\hline Crude fiber & $\mathbf{0 . 8 2} \pm \mathbf{0 . 4 1}$ & $\mathbf{0 . 7 1} \pm \mathbf{0 . 3 3}$ & $\mathbf{8 . 3 6} \pm \mathbf{0 . 8 3}$ \\
\hline Total dietary fiber & $\mathbf{3 . 0 8} \pm \mathbf{0 . 2 1}$ & $\mathbf{2 . 9 2} \pm \mathbf{0 . 1 0}$ & $\mathbf{1 9 . 3 5} \pm \mathbf{0 . 3 6}$ \\
\hline Insoluble dietary fiber & $\mathbf{2 . 0 7} \pm \mathbf{0 . 0 9}$ & $\mathbf{1 . 9 5} \pm \mathbf{0 . 1 2}$ & $\mathbf{1 2 . 6 4} \pm \mathbf{0 . 1 5}$ \\
\hline Soluble dietary fiber & $\mathbf{1 . 0 1} \pm \mathbf{0 . 0 6}$ & $\mathbf{0 . 9 7} \pm \mathbf{0 . 0 5}$ & $\mathbf{6 . 7 1} \pm \mathbf{0 . 1 0}$ \\
\hline Ash & $\mathbf{0 . 9 2} \pm \mathbf{0 . 1 0}$ & $\mathbf{0 . 5 6} \pm \mathbf{0 . 0 6}$ & $\mathbf{8 . 6 4} \pm \mathbf{0 . 3 3}$ \\
\hline *Total carbohydrates & $\mathbf{8 4 . 7 9} \pm \mathbf{2 . 2 5}$ & $\mathbf{8 6 . 2 0} \pm \mathbf{2 . 6 9}$ & $\mathbf{6 7 . 7 6} \pm \mathbf{2 . 1 2}$ \\
\hline
\end{tabular}


dietary fiber content had the highest values in rice bran $(19.35 \pm 0.36 \%)$ compared with wheat flours as well as insoluble and soluble dietary fibers. However, total carbohydrates were lower than those in wheat flours, these results indicated that rice bran could be considered as a good source of crude fiber and total dietary fiber. It also contained considerable amount of crude protein. These results demonstrated the potential use of rice bran in the production of bakery products. The present results are in good agreement with the results of Doweidar et al. (2010) for wheat flour and Hamid et al. (2007) for rice bran.

\subsection{Chemical composition of different substituted pan bread samples}

Pan bread samples prepared by replacement of wheat flour (82\% extraction) with rice bran at different levels (5\%, 10\% and 15\%) were chemically analyzed and the results are shown in Table (2). The results indicated that the moisture contents of pan bread samples substituted with rice bran were higher than that that the total dietary fiber, soluble and insoluble dietary fibers were increased in pan bread samples as a result of substitution with different levels of rice bran. Total dietary fiber content increased from $3.37 \pm 0.14 \%$ (control pan bread) to $5.45 \pm 0.63 \%$ (pan bread sample containing $15 \%$ rice bran). Total dietary fiber increased by 1.1, 1.4 and 1.6 folds for pan bread samples substituted with $5 \%, 10 \%$ and $15 \%$ rice bran, respectively, compared with the control sample. Bread as processed cereal products seemed to be a part of the daily diet for most people. These products are low in fat and good sources of complex carbohydrates but they are not good sources of dietary fiber, in particular, soluble fiber (Anderson et al., 1999). The obtained results indicated that rice bran could be considered as a rich source of total dietary fiber, soluble fiber and ash in pan bread making. Addition of rice bran to wheat flour increased the contents of protein, lysine and dietary fiber in bread and cookies proportionately to the level of substitution (Sharma and Chauhan, 2002).

Table (2): Chemical composition of different substituted pan bread samples (\% dry weight basis).

\begin{tabular}{|c|c|c|c|c|}
\hline \multirow[t]{2}{*}{ Constituents } & \multirow{2}{*}{$\begin{array}{l}\text { Control pan bread } \\
(100 \% \text { wheat } \\
\text { flour })\end{array}$} & \multicolumn{3}{|c|}{ Pan bread samples substituted with rice bran } \\
\hline & & $5 \%$ Rice bran & $10 \%$ Rice bran & $15 \%$ Rice bran \\
\hline Moisture & $33.62 \pm 1.24$ & $35.42 \pm 1.13$ & $36.53 \pm 1.10$ & $38.12 \pm 1.12$ \\
\hline Crude protein & $12.14 \pm 0.16$ & $12.83 \pm 0.10$ & $13.52 \pm 0.16$ & $14.14 \pm 0.15$ \\
\hline Ether extract & $1.85 \pm 0.63$ & $1.96 \pm 0.13$ & $2.25 \pm 0.10$ & $2.63 \pm 0.16$ \\
\hline Crude fiber & $1.12 \pm 0.52$ & $1.62 \pm 0.15$ & $1.92 \pm 0.17$ & $2.15 \pm 0.11$ \\
\hline Total dietary fiber & $3.37 \pm 0.14$ & $3.95 \pm 0.61$ & $4.76 \pm 0.16$ & $5.45 \pm 0.63$ \\
\hline Insoluble dietary fiber & $2.26 \pm 0.21$ & $2.65 \pm 0.24$ & $3.19 \pm 0.13$ & $3.65 \pm 0.22$ \\
\hline Soluble dietary fiber & $1.11 \pm 0.09$ & $1.30 \pm 0.10$ & $1.57 \pm 0.13$ & $1.80 \pm 0.15$ \\
\hline Ash & $1.77 \pm 0.08$ & $2.19 \pm 0.11$ & $2.63 \pm 0.16$ & $3.06 \pm 0.11$ \\
\hline *Total carbohydrates & $83.12 \pm 1.67$ & $81.40 \pm 1.31$ & $79.68 \pm 1.23$ & $78.02 \pm 1.62$ \\
\hline
\end{tabular}

*Total carbohydrates $=100-(\%$ protein $+\%$ fat $+\%$ fiber $+\%$ ash $)$.

of pan bread made from 100\% wheat flour (control). Addition of rice bran to wheat flour (82\% extraction) increased protein content of different substituted pan bread samples and the higher the level of rice bran in the bread sample, the higher the protein content. As the amount of rice bran was increased in the flour mixtures, crude fat present in their pan bread was increased in comparison with the control pan bread (100\% wheat flour). The crude fiber and ash contents of pan bread samples substituted with rice bran were high compared with the control pan bread sample. Increasing the amount of rice bran in the flour mixtures caused a gradual increase in crude fiber and ash contents in pan bread samples. On the contrary, total carbohydrates decreased as the substitution levels of rice bran increased. It could be noticed

\subsection{Physical properties of different substituted pan bread samples}

Different prepared pan bread samples were subjected to some physical measurements including: weight, volume, density and specific volume of the loaves (Table 3). The obtained results indicated that as the substitution levels of rice bran increased, weight and density of pan bread increased. On the other hand, volume and specific volume of pan bread loaves were significantly decreased with the increase of rice bran addition. The changes in the loaves volume may be due to the change in the quality and quantity of protein as a result of rice bran addition. Specific volume is a very important characteristic as it measures the loaf density, the lower the specific volume the more density and compact of the bread. The greater rising volume 
Table (3): Physical properties of different substituted pan bread samples.

\begin{tabular}{|c|c|c|c|c|}
\hline Pan bread samples & Weight (g) & Volume (cm3) & Specific volume $(\mathrm{cm} 3 / \mathrm{g})$ & Density (g/cm3) \\
\hline Control pan bread & 137.63d & 327.25a & $2.38 \mathrm{a}$ & $0.421 d$ \\
\hline $5 \%$ Rice bran & $139.15 c$ & 321.75b & $2.31 b$ & $0.432 c$ \\
\hline $10 \%$ Rice bran & 141.35b & $319.12 c$ & $2.26 \mathrm{c}$ & $0.443 b$ \\
\hline $15 \%$ Rice bran & 146.30a & 313.50d & $2.14 d$ & $0.467 a$ \\
\hline L.S.D. & 1.26 & 2.46 & 0.036 & 0.006 \\
\hline
\end{tabular}

Numbers in the same column with the different letters are significantly different at $\mathrm{p}<0.05$

for control pan bread sample over the substituted pan bread samples probably resulted from the higher ability of gluten to trap carbon dioxide gas liberated during baking (Nielson, 2002).

\subsection{Chemical composition of different} substituted salted biscuit samples

Salted biscuit samples prepared by replacement of wheat flour (72\% extraction) with different levels of rice bran $(5 \%, 10 \%$ and $15 \%$ ) were analyzed and the results are presented in Table (4). The results revealed that addition of rice bran to wheat flour increased protein content of different substituted salted biscuits and the higher the level of rice bran in biscuit sample, the higher the protein content.
It could be also noticed that the total dietary fiber, insoluble and soluble dietary fibers increased in all salted biscuit samples as a result of substitution with different levels of rice bran. The increment percentages of total dietary fiber ranged from $50.31 \%$ to $135.49 \%$ for different substituted salted biscuit samples compared with the control sample (100\% wheat flour). Addition of different levels of rice bran also increased soluble and insoluble dietary fiber contents. The obtained results are in accordance with the results reported by Emperatriz (2005), who found that the content of total dietary fiber of pizza dough increased as the substitution level of stabilized rice bran flour increased.

Table (4): Chemical composition of different substituted salted biscuit samples (\% dry weight basis).

\begin{tabular}{|c|c|c|c|c|}
\hline \multirow[t]{2}{*}{ Constituents } & \multirow{2}{*}{$\begin{array}{l}\text { Control salted biscuits } \\
\text { (100\% wheat flour) }\end{array}$} & \multicolumn{3}{|c|}{ Salted biscuits substituted with rice bran } \\
\hline & & 5\% Rice bran & $10 \%$ Rice bran & $15 \%$ Rice bran \\
\hline Moisture & $5.43 \pm 0.16$ & $6.21 \pm 0.13$ & $6.64 \pm 0.19$ & $6.87 \pm 0.17$ \\
\hline Crude protein & $11.06 \pm 0.11$ & $11.75 \pm 0.11$ & $12.43 \pm 0.13$ & $13.15 \pm 0.17$ \\
\hline Ether extract & $6.74 \pm 0.10$ & $6.90 \pm 0.13$ & $7.52 \pm 0.10$ & $7.84 \pm 0.13$ \\
\hline Crude fiber & $0.83 \pm 0.05$ & $1.44 \pm 0.03$ & $2.67 \pm 0.08$ & $2.91 \pm 0.09$ \\
\hline Total dietary fiber & $3.24 \pm 0.10$ & $4.87 \pm 0.90$ & $6.35 \pm 0.70$ & $7.63 \pm 0.31$ \\
\hline Insoluble dietary fiber & $2.17 \pm 0.07$ & $3.48 \pm 0.11$ & $4.64 \pm 0.17$ & $5.74 \pm 0.25$ \\
\hline Soluble dietary fiber & $1.07 \pm 0.12$ & $1.39 \pm 0.16$ & $1.71 \pm 0.14$ & $1.89 \pm 0.17$ \\
\hline Ash & $1.13 \pm 0.06$ & $1.52 \pm 0.13$ & $2.03 \pm 0.16$ & $2.44 \pm 0.11$ \\
\hline *Total carbohydrates & $80.24 \pm 1.85$ & $78.39 \pm 2.31$ & $75.35 \pm 1.63$ & $73.66 \pm 1.45$ \\
\hline
\end{tabular}

*Total carbohydrates $=100-(\%$ protein $+\%$ fat $+\%$ fiber $+\%$ ash $)$.

Increasing rice bran substitution to wheat flour caused a slight increase in fat content of salted biscuits samples. Fat is a vital ingredient in baked goods, providing flavor and taste as well as contributing to texture, tenderness and appearance of the products (Zoulias et al., 2000). The results showed similar trend for crude fiber and ash contents of salted biscuits as that of protein. On the contrary, total carbohydrates were decreased as the substitution levels of rice bran increased. Dietary fiber from rice bran exhibited higher water and fat binding capacities and hydro-colloidal fibers have the ability to create a tridimensional matrix, holding not only water but also fat added to the formula, avoiding losses of fat and water during baking (Hamid and Luan, 2000).

\subsection{Physical properties of different substituted salted biscuit samples}

Data presented in Table (5) showed that all measured physical properties of the tested salted biscuit samples showed significant differences from the control. The results indicated that as the substitution levels of rice bran increased, weight and density of salted biscuits increased. Volume and specific volume were significantly decreased with the increase in rice bran addition. The highest increase in weight and density of salted biscuits was achieved by substitution with rice bran at the levels of $15 \%$ and $10 \%$, respectively, compared with the control biscuit $(100 \%$ wheat flour). The increase in weight of the substituted biscuit samples might be attributed to the high level of fibers in rice bran used for substitution, 
which increased water absorption and affected weight of the samples (Mahfouz et al., 2007). The reduction of volume and specific volume might be due to the influence of rice bran replacing levels on gluten dilution of wheat flour which cause a reduction in the gluten strength and consequently on the net-work formed (Hafez, 2004).

Table (5): Physical properties of different substituted salted biscuit samples.

\begin{tabular}{|l|c|c|c|c|}
\hline $\begin{array}{l}\text { Salted } \\
\text { biscuits } \\
\text { samples }\end{array}$ & $\begin{array}{c}\text { Weight } \\
(\mathrm{g})\end{array}$ & $\begin{array}{c}\text { Volume } \\
(\mathrm{cm3})\end{array}$ & $\begin{array}{c}\text { Specific } \\
\text { volume } \\
(\mathrm{cm} 3 / \mathrm{g})\end{array}$ & $\begin{array}{c}\text { Density } \\
(\mathrm{g} / \mathrm{cm} 3)\end{array}$ \\
\hline $\begin{array}{l}\text { Control } \\
\text { salted biscuits }\end{array}$ & $12.16 \mathrm{~d}$ & $30.46 \mathrm{a}$ & $2.50 \mathrm{a}$ & $\mathbf{0 . 3 9 9 d}$ \\
\hline 5\% rice bran & $13.84 \mathrm{c}$ & $26.23 \mathrm{~b}$ & $1.89 \mathrm{~b}$ & $\mathbf{0 . 5 2 8 c}$ \\
\hline $\begin{array}{l}\text { 10\% rice } \\
\text { bran }\end{array}$ & $15.08 \mathrm{~b}$ & $21.67 \mathrm{c}$ & $1.44 \mathrm{c}$ & $\mathbf{0 . 6 9 6 b}$ \\
\hline $\begin{array}{l}15 \% \text { rice } \\
\text { bran }\end{array}$ & $15.96 \mathrm{a}$ & $19.55 \mathrm{~d}$ & $1.22 \mathrm{~d}$ & $\mathbf{0 . 8 1 6 a}$ \\
\hline L.S.D. & 0.75 & 2.08 & 0.19 & 0.09 \\
\hline
\end{tabular}

Numbers in the same column with the different letters are significantlv different at $\mathrm{p}<0.05$

\subsection{Sensory evaluation of different substituted pan bread samples}

Data presented in Table (6) showed the sensory evaluation of different substituted pan bread samples with different levels of rice bran. There were insignificant differences for crust color, crump color, homogenits, taste odor and overall acceptability between $5 \%$ and $10 \%$ rice bran substituted pan bread samples, while appearance and crump distribution were significantly different. There were insignificant differences for appearance between the control pan bread sample and $10 \%$ rice bran substituted pan bread sample and between control sample and $5 \%$ rice bran substituted pan bread sample for crump distribution characteristics. Substitution with rice bran at levels of $5 \%$ and $10 \%$ in pan bread making caused an improvement in odor of produced pan bread, while $15 \%$ rice bran substituted sample recorded the lowest scores for all sensory attributes and was significantly different compared with all other treatments. There was insignificant difference between $5 \%$ and $10 \%$ rice bran substituted pan bread samples for overall acceptability scores. The highest overall acceptability scores were recorded for the control pan bread, followed by either $5 \%$ or $10 \%$ rice bran substituted pan bread samples, while $15 \%$ rice bran substituted pan bread sample recorded the lowest overall acceptability score.

\subsection{Sensory evaluation of different substituted salted biscuit samples}

Sensory evaluation of different substituted salted biscuit samples with different levels of rice bran was shown in Table (7). There were insignificant differences between $5 \%$ and $10 \%$ rice bran substituted salted biscuit samples for color and odor attributes. Addition of $15 \%$ rice bran to wheat flour caused a significant reduction in all sensory attributes of salted biscuits compared with other treatments. The differences among overall acceptability were more pronounced. There were insignificant differences for salted biscuit samples substituted with $5 \%$ and $10 \%$ rice bran, while biscuit samples containing $15 \%$ rice bran were significantly different compared with other treatments for overall acceptability scores. The lowest overall acceptability score was achieved by using $15 \%$ rice bran added to wheat flour. The low acceptability of biscuits from blends containing more than $10 \%$ rice bran was attributed to appearance, color and taste. In conclusion, chemical composition, physical properties and sensory evaluation of both pan bread and salted biscuit samples, proved that the level of $10 \%$ rice bran was the best level for substitution of wheat flour to produce these bakery products Thus, further studies was concerued with its nutritional and biological values.

\subsection{Mineral contents of bakery products}

Data presented in Table (8) showed the mineral contents of pan bread and salted biscuit samples substituted with $10 \%$ rice bran as well as the control sample. The results showed an increase in all mineral contents for both pan bread and salted biscuits substituted with $10 \%$ rice bran compared with the control pan bread and control salted biscuits (100\% wheat flours of $82 \%$ and $72 \%$ extractions, respectively). Pan bread samples substituted with $10 \%$ rice bran should contribute approximately to about 3\%, $9 \%, 5 \%, 3 \%, 64 \%, 24 \%$ and $13 \%$ of $\mathrm{K}, \mathrm{Mg}, \mathrm{Ca}$, $\mathrm{Na}, \mathrm{Mn}, \mathrm{Fe}$ and $\mathrm{Zn}$, respectively, of the Recommended Daily Allowances (RDA) reported by NRC (2010). Salted biscuit samples substituted with $10 \%$ rice bran contributed approximately to about 3, 4, 9, 26, 59, 15 and $9 \%$ of $\mathrm{K}, \mathrm{Mg}, \mathrm{Ca}, \mathrm{Na}, \mathrm{Mn}, \mathrm{Fe}$ and $\mathrm{Zn}$, respectively, of the RDA. The present results indicated that the presence of rice bran caused an increase in all minerals in the substituted bakery products and consequently improved the nutritive value of wheat flour. The present 
Table (6): Sensory evaluation of different substituted pan bread samples.

\begin{tabular}{|c|c|c|c|c|c|c|c|c|}
\hline $\begin{array}{l}\text { Pan } \\
\text { bread } \\
\text { samples }\end{array}$ & $\begin{array}{c}\text { Appearance } \\
\text { (10) }\end{array}$ & $\begin{array}{l}\text { Crust } \\
\text { color } \\
(15) \\
\end{array}$ & $\begin{array}{c}\text { Crump } \\
\text { color } \\
\text { (15) }\end{array}$ & $\begin{array}{c}\text { Crump } \\
\text { distribution } \\
(15)\end{array}$ & $\begin{array}{l}\text { Homogenous } \\
\text { (15) }\end{array}$ & $\begin{array}{l}\text { Taste } \\
\text { (15) }\end{array}$ & $\begin{array}{c}\text { Odor } \\
\text { (15) }\end{array}$ & $\begin{array}{c}\text { Overall } \\
\text { acceptability } \\
(\mathbf{1 0 0})\end{array}$ \\
\hline $\begin{array}{l}\text { Control } \\
\text { pan } \\
\text { bread }\end{array}$ & $9.1^{\mathrm{a}}$ & $14.6^{a}$ & $13.2^{\mathrm{a}}$ & $13.1^{\mathrm{a}}$ & $14.0^{a}$ & $13.1^{\mathrm{ab}}$ & $12.3^{b}$ & $89.4^{\mathrm{a}}$ \\
\hline $\begin{array}{l}5 \% \text { Rice } \\
\text { bran }\end{array}$ & $8.1^{b}$ & $13.1^{b}$ & $12.4^{b}$ & $13.7^{a}$ & $13.6^{b}$ & $13.2^{\mathrm{a}}$ & $13.0^{\mathrm{a}}$ & $87.1^{b}$ \\
\hline $\begin{array}{l}10 \% \text { Rice } \\
\text { bran }\end{array}$ & $8.8^{\mathrm{a}}$ & $13.6^{b}$ & $12.7^{b}$ & $12.3^{b}$ & $13.5^{b}$ & $13.7^{\mathrm{a}}$ & $13.4^{\mathrm{a}}$ & $88.0^{b}$ \\
\hline $\begin{array}{l}15 \% \text { Rice } \\
\text { bran }\end{array}$ & $7.3^{c}$ & $12.1^{\mathrm{c}}$ & $11.3^{\mathrm{c}}$ & $10.6^{c}$ & $11.5^{\mathrm{c}}$ & $12.3^{\mathrm{c}}$ & $11.2^{\mathrm{c}}$ & $76.2^{c}$ \\
\hline L.S.D. & 0.36 & $\mathbf{0 . 8 3}$ & 0.46 & 0.64 & 0.38 & 0.54 & 0.50 & 1.23 \\
\hline
\end{tabular}

Numbers in the same column with the different letters are significantly different at $p<0.05$

Table (7): Sensory evaluation of different substituted salted biscuit samples.

\begin{tabular}{|c|c|c|c|c|c|c|c|c|}
\hline $\begin{array}{l}\text { Salted biscuits } \\
\text { samples }\end{array}$ & $\begin{array}{c}\text { Appearance } \\
(\mathbf{1 0})\end{array}$ & $\begin{array}{l}\text { Color } \\
\text { (15) }\end{array}$ & $\begin{array}{c}\text { Thickness } \\
\text { (15) }\end{array}$ & $\begin{array}{l}\text { Crispiness } \\
\text { (15) }\end{array}$ & $\begin{array}{c}\text { Shrinkage } \\
\text { (15) }\end{array}$ & $\begin{array}{l}\text { Taste } \\
\text { (15) }\end{array}$ & $\begin{array}{c}\text { Odor } \\
(15)\end{array}$ & $\begin{array}{c}\text { Overall } \\
\text { acceptability } \\
(100)\end{array}$ \\
\hline $\begin{array}{l}\text { Control salted } \\
\text { biscuits }\end{array}$ & $9.1^{\mathrm{a}}$ & $13.3^{\mathrm{a}}$ & $13.6^{\mathrm{a}}$ & $13.2^{\mathrm{a}}$ & $13.3^{\mathrm{a}}$ & $13.1^{\mathrm{a}}$ & $13.6^{\mathrm{a}}$ & $89.2^{\mathrm{a}}$ \\
\hline $5 \%$ Rice bran & $8.0^{\mathrm{c}}$ & $12.4^{\mathrm{b}}$ & $12.7^{b}$ & $12.8^{b}$ & $12.1^{\mathrm{c}}$ & $12.7^{b}$ & $12.1^{\mathrm{b}}$ & $82.8^{b}$ \\
\hline $10 \%$ Rice bran & $8.6^{b}$ & $12.7^{b}$ & $12.4^{\mathrm{c}}$ & $13.3^{\mathrm{a}}$ & $12.5^{b}$ & $12.4^{\mathrm{c}}$ & $12.6^{b}$ & $84.5^{b}$ \\
\hline $15 \%$ Rice bran & $7.3^{d}$ & $11.2^{\mathrm{c}}$ & $11.7^{d}$ & $10.5^{\mathrm{c}}$ & $11.5^{d}$ & $10.7^{d}$ & $11.0^{\mathrm{c}}$ & $73.9^{\mathrm{c}}$ \\
\hline L.S.D. & 0.54 & 0.43 & 0.26 & 0.15 & 0.27 & 0.21 & 0.95 & 2.34 \\
\hline
\end{tabular}

Numbers in the same column with the different letters are significantly different at $p<0.05$

Table (8): Mineral contents of bakery products (mg/100g).

\begin{tabular}{|l|l|l|l|l|l|}
\hline Mineral contents & $\begin{array}{l}\text { Control } \\
\text { pan bread }\end{array}$ & $\begin{array}{l}\text { 10\% Rice bran } \\
\text { pan bread }\end{array}$ & $\begin{array}{l}\text { Control } \\
\text { salted biscuits }\end{array}$ & $\begin{array}{l}\text { 10\% Rice bran } \\
\text { salted biscuits }\end{array}$ & RDA* $^{*}$ \\
\hline Potassium (K) & $\mathbf{1 1 6 . 3 0} \pm \mathbf{1 0 . 3 1}$ & $\mathbf{1 5 7 . 1 3} \pm \mathbf{9 . 1 2}$ & $\mathbf{1 3 6 . 1 1} \pm \mathbf{1 0 . 2 5}$ & $\mathbf{1 8 3 . 1 4} \pm \mathbf{1 1 . 1 2}$ & $\mathbf{4 7 0 0}$ \\
\hline Magnesium $(\mathbf{M g})$ & $\mathbf{2 0 . 3 2} \pm \mathbf{1 . 6 3}$ & $\mathbf{3 6 . 2 5} \pm \mathbf{1 . 7 2}$ & $\mathbf{1 1 . 6 5} \pm \mathbf{1 . 4 1}$ & $\mathbf{1 7 . 1 6} \pm \mathbf{1 . 5 3}$ & $\mathbf{4 0 0}$ \\
\hline Calcium $(\mathrm{Ca})$ & $\mathbf{4 5 . 1 1} \pm \mathbf{1 . 5 5}$ & $\mathbf{5 2 . 6 3} \pm \mathbf{1 . 3 3}$ & $\mathbf{9 1 . 8 4} \pm \mathbf{3 . 1 1}$ & $\mathbf{9 9 . 1 8} \pm \mathbf{3 . 6 5}$ & $\mathbf{1 0 0 0}$ \\
\hline Sodium $(\mathbf{N a})$ & $\mathbf{3 9 . 1 4} \pm \mathbf{1 . 1 7}$ & $\mathbf{5 6 . 2 1} \pm \mathbf{1 . 1 5}$ & $\mathbf{3 6 2 . 6 0} \pm \mathbf{1 6 . 1 4}$ & $\mathbf{3 9 4 . 1 4} \pm \mathbf{1 2 . 6 3}$ & $\mathbf{1 5 0 0}$ \\
\hline Manganese $(\mathrm{Mn})$ & $\mathbf{1 . 0 7} \pm \mathbf{0 . 9 1}$ & $\mathbf{1 . 4 8} \pm \mathbf{0 . 6 7}$ & $\mathbf{1 . 2 5} \pm \mathbf{0 . 4 1}$ & $\mathbf{1 . 3 7} \pm \mathbf{0 . 5 3}$ & $\mathbf{2 . 3 0}$ \\
\hline Iron $(\mathrm{Fe})$ & $\mathbf{2 . 7 8} \pm \mathbf{0 . 8 3}$ & $\mathbf{3 . 6 2} \pm \mathbf{0 . 7 1}$ & $\mathbf{1 . 9 3} \pm \mathbf{0 . 6 3}$ & $\mathbf{2 . 3 4} \pm \mathbf{0 . 6 7}$ & $\mathbf{1 5 . 0 0}$ \\
\hline Zinc $(\mathrm{Zn})$ & $\mathbf{0 . 8 8} \pm \mathbf{0 . 0 6}$ & $\mathbf{1 . 4 3} \pm \mathbf{0 . 0 9}$ & $\mathbf{1 . 0 3} \pm \mathbf{0 . 0 7}$ & $\mathbf{1 . 0 9} \pm \mathbf{0 . 0 5}$ & $\mathbf{1 1 . 0 0}$ \\
\hline
\end{tabular}

RDA*, Recommended Daily Allowances by National Research Council (2010). 
results are in the same line with the results reported by Abd El-Galeel and El-Bana (2012) showing the increase in mineral contents of $10 \%$ defatted rice bran substituted biscuits.

\subsection{Nutritive value of bakery products}

From the results illustrated in Tables ( 2 and 4) for the chemical composition of pan bread and salted biscuit samples, the nutritive value including: \%DRI (Dietary Reference Intake of total dietary fiber), classification of bakery products according to the amount of fiber, soluble to insoluble dietary fiber ratio and calorific value of products were calculated. Total phenolic compounds and antioxidant activity were also measured and the obtained results are presented in Table (9). The results of the present study indicated that the \% DRI of dietary fiber ranged from $12.96 \%$ for control salted biscuits sample to $25.40 \%$ for $10 \%$ rice bran salted biscuits sample. It was observed that both control pan bread and salted biscuits samples and $10 \%$ rice bran pan bread sample could be considered to be good sources of dietary fiber, while $10 \%$ rice bran salted biscuits sample could be considered as an excellent source of dietary fiber. The soluble dietary fiber (SDF) to insoluble dietary fiber (IDF) ratio is important factor for both dietary fiber and functional property. It is generally accepted that those fiber sources suitable for use as food
Total phenolic contents of both $10 \%$ rice bran pan bread and $10 \%$ rice bran salted biscuits samples were higher than those of both control pan bread and control salted biscuits samples (Table 9). However, the total phenolic contents of $10 \%$ rice bran pan bread were higher than $10 \%$ rice bran biscuits because of using wheat flour $82 \%$ extraction in pan bread making. The increment percentages were $180.70 \%$ and $188.95 \%$ for $10 \%$ rice bran pan bread and $10 \%$ rice bran salted biscuit, respectively, compared with control samples. The prepared pan bread and salted biscuits samples had sufficient amount of phenolics compared to the control samples, which have no rice bran levels due to components derived from rice bran in the substituted samples. Rice bran contained phenolic compounds including tocopherols, tocotrienols and $\gamma$-oryzanol, which have a strong correlation with rice bran antioxidant activity (Iqbal et al.,2005).

Concerning antioxidant activity of samples, it was observed that both $10 \%$ rice bran pan bread and $10 \%$ rice bran salted biscuits contained higher antioxidant activity than those of the control samples and the increase in antioxidant activity was $141.03 \%$ and $120.53 \%$, respectively, compared with the control samples as a result of rice bran addition. It was concluded that $100 \mathrm{~g}$ of these bakery products could be considered

Table (9): Nutritive value of bakery products provided to adults as $100 \mathrm{~g}$ serving.

\begin{tabular}{|l|l|l|l|l|}
\hline Nutritive value & $\begin{array}{l}\text { Control } \\
\text { pan bread }\end{array}$ & $\begin{array}{l}10 \% \text { Rice bran } \\
\text { pan bread }\end{array}$ & $\begin{array}{l}\text { Control } \\
\text { salted biscuits }\end{array}$ & $\begin{array}{l}10 \% \text { Rice bran } \\
\text { salted biscuits }\end{array}$ \\
\hline \% DRI* & 13.48 & 19.04 & 12.96 & 25.40 \\
\hline Classification & Good source & Good source & Good source & Excellent source \\
\hline SDF/IDF ratio & $1: 2$ & $1: 2$ & $1: 2$ & $1: 2$ \\
\hline Calorific value $($ K.cal/100g) & 407.39 & 402.59 & 435.66 & 428.32 \\
\hline Total phenolic contents $(\mathbf{m g} / 100 g)$ & $\mathbf{8 6 . 6 7} \pm 1.73$ & $\mathbf{2 4 3 . 2 8} \pm 11.34$ & $\mathbf{7 6 . 5 4} \pm 1.51$ & $\mathbf{2 2 1 . 1 6 \pm 1 1 . 1 3}$ \\
\hline Antioxidant activity $(\mu \mathrm{g} / \mathrm{ml})$ & $\mathbf{5 . 6 3} \pm \mathbf{0 . 7 2}$ & $\mathbf{1 3 . 5 7} \pm 1.06$ & $4.87 \pm 0.84$ & $10.74 \pm 1.03$ \\
\hline
\end{tabular}

$\%$ DRI* = Total dietary fiber / $25 \times 100$

ingredient should have an SDF/IDF ratio close to 1:2 (Jaime et al., 2002). This ratio was achieved for both control pan bread and salted biscuits samples and also for $10 \%$ rice bran substituted bakery products. The calorific value of both $10 \%$ rice bran pan bread and $10 \%$ rice bran salted biscuits samples was decreased compared with control samples $(100 \%$ wheat flours of $82 \%$ and $72 \%$ extractions, respectively).Dietary guidelines recommended that, total carbohydrates intake should be $\geq 130 \mathrm{~g} /$ day and total dietary fiber intake should be $28 \mathrm{~g} / 2000 \mathrm{~K}$.cal/day (Bantle et al., 2006). nutritious in terms of total dietary fiber, phenolic contents and have an antioxidant activity. These bakery products might be used for people with special health conditions such as diabetics and elevated serum cholesterol subjects.

\subsection{Biological value of bakery products}

The amino acid contents and biological value of control pan bread and salted biscuits and those bakery products substituted with $10 \%$ rice bran were shown in Table (10). The results showed that the substitution of wheat flour with rice bran resulted in an increase in all the essential amino acids (threonine, isoleucine, 
leucine, lysine, valine, phenylalanine and methionine + cystine) compared with control pan bread and salted biscuits samples (100\% wheat flour). The increase in these essential amino acids in substituted pan bread and salted biscuits was: $12.23,19.02,27.13,9.98,13.49$, 14.46 and $21.68 \%$, respectively, for $10 \%$ rice bran pan bread sample and 10.36, 5.08, 31.87, $18.34,11.61,27.75$ and $16.09 \%$, respectively, for $10 \%$ rice bran salted biscuit samples compared with the control samples. Consequently, the total essential amino acids were increased in substituted pan bread and salted biscuits by $17.31 \%$ and $19.76 \%$, respectively, compared with control pan bread and salted biscuits substituted with $10 \%$ rice bran. Rice bran contained a balanced spectrum of hypoallergenic nutritive protein with a well balanced amino acid composition (Hoogenkamp, 2008).

From data presented in Table (10) it could be also observed that, both protein efficiency ratio and biological value were increased in $10 \%$ rice bran substituted pan bread and salted biscuits samples compared with control samples $(100 \%$ wheat flour). The increase in protein efficiency ratio was $23.05 \%$ and $28.28 \%$ for $10 \%$ rice bran substituted pan bread and salted biscuits samples, respectively. Biological value was increased by $9.14 \%$ and $10.80 \%$ for both bakery products, respectively.

Table (10): Amino acids contents (g/16g nitrogen) and biological value of bakery products.

\begin{tabular}{|c|c|c|c|c|c|c|c|c|c|}
\hline \multirow[t]{2}{*}{ Amino acids } & \multicolumn{2}{|c|}{$\begin{array}{c}\text { Control pan } \\
\text { bread }\end{array}$} & \multicolumn{2}{|c|}{$\begin{array}{l}10 \% \text { Rice bran } \\
\text { pan bread }\end{array}$} & \multicolumn{2}{|c|}{$\begin{array}{c}\text { Control salted } \\
\text { biscuits }\end{array}$} & \multicolumn{2}{|c|}{$\begin{array}{l}10 \% \text { Rice bran } \\
\text { salted biscuits }\end{array}$} & \multirow[t]{2}{*}{$\begin{array}{c}\text { FAO/WHO } \\
(2008)\end{array}$} \\
\hline & Contents & A.S. & Contents & A.S. & Contents & A.S. & Contents & A.S. & \\
\hline Threonine & 3.76 & 25.07 & 4.22 & 28.13 & 2.22 & 14.80 & 2.45 & 16.33 & 15 \\
\hline Isoleucine & 3.47 & 17.35 & 4.13 & 20.65 & 2.56 & 12.80 & 2.69 & 13.45 & 20 \\
\hline Leucine & 6.23 & 15.97 & 7.92 & 20.31 & 5.93 & 15.20 & 7.82 & 20.05 & 39 \\
\hline Lysine & 4.31 & 14.37 & 4.74 & 15.80 & 4.09 & 13.63 & 4.84 & 16.13 & 30 \\
\hline Valine & 4.67 & 17.96 & 5.30 & 20.38 & 3.53 & 13.58 & 3.94 & 15.15 & 26 \\
\hline Phenylalanine & 4.77 & 19.08 & 5.46 & 21.84 & 4.36 & $\mathbf{1 7 . 4 4}$ & 5.57 & 22.28 & 25 \\
\hline Methionine + cystine & 3.46 & 11.53 & 4.21 & 14.03 & 3.73 & 12.43 & 4.33 & 14.43 & 30 \\
\hline $\begin{array}{l}\text { Total essential amino } \\
\text { acids }\end{array}$ & 30.67 & 16.58 & 35.98 & 19.45 & 26.42 & 14.28 & 31.64 & $\mathbf{1 7 . 1 0}$ & 185 \\
\hline Histidine & 2.92 & 29.20 & 3.38 & 33.80 & 3.28 & 32.80 & 4.17 & 41.70 & 10 \\
\hline Tryptophan & 1.13 & 28.25 & 1.46 & 36.50 & 1.76 & 44.00 & 2.15 & 53.75 & 4 \\
\hline Proline & 9.47 & ----- & 10.69 & $-\cdots--$ & 10.43 & ----- & 11.35 & ----- & \\
\hline $\begin{array}{l}\text { Protein efficiency } \\
\text { ratio (PER) } \\
\text { Biological value (BV } \\
\% \text { ) }\end{array}$ & \multicolumn{2}{|c|}{$\begin{array}{c}3.08 \\
81.83\end{array}$} & \multicolumn{2}{|c|}{$\begin{array}{c}\mathbf{3 . 7 9} \\
\mathbf{8 9 . 3 1}\end{array}$} & \multicolumn{2}{|c|}{$\begin{array}{c}2.80 \\
79.94\end{array}$} & \multicolumn{2}{|c|}{$\begin{array}{c}3.72 \\
88.57\end{array}$} & \\
\hline
\end{tabular}

FAO/WHO/UNU* Reference protein for adults (2008).

Amino acid scores (A.S.), protein efficiency ratio (PER) and biological value (BV) were calculated by equations.

samples. The nutritional quality of protein is dependent upon the effectiveness of the test protein in meeting the amino acids requirements and the degree of retention of the component amino acids during processing ( $\mathrm{FAO} / \mathrm{WHO}$, 2008). From the present results it could be observed that, the high quality protein of both pan bread and salted biscuits samples substituted with $10 \%$ rice bran was confirmed by calculating chemical scores (A.S.), which were found to be higher than the control samples. The amino acids scores showed that methionine + cystine and lysine were the first and second limiting amino acids for pan bread, while isoleucine and methionine + cystine were the first and seemd limiting amino acids for salted biscuits. However, the other amino acids gave higher scores, indicating that degree of excellence was given for pan bread and salted biscuits

\section{In conclusion}

It could be concluded that replacement of wheat flour with $10 \%$ rice bran can be followed without any adverse effects on physical and sensory characteristics of bakery products (pan bread and salted biscuits). Both types of bakery products prepared with rice bran showed an improvement in the contents of total dietary fiber, crude fiber, ash and total phenolic contents compared with control samples. Minerals, amino acids scores, protein efficiency ratio and biological value were also improved by substitution with rice bran. It can be recommended that using composite flour should be encouraged to make economic use of local raw materials and to produce high quality food products for the populations of developing countries. 


\section{REFERENCES}

A.A.C.C. (2002). Approved Methods of American Association of Cereal Chemists. Published by American Association of Cereal Chemists. Inc., St., Paul, Minnesota, USA., 15: 562-564.

Abd El-Galeel M. A. and El-Bana M. E. (2012). Effect of milling degree on chemical composition and nutritional value of stabilized rice bran. J. Agric. Res. Kafr ElSheikh Univ., 38 (4): 556-567.

Alsmeyer R. H.,Cunningham A. E. and Happich M. L. (1974). Equations predict PER from amino acid analysis. Food Technol., 28: 34.

Anderson J. W., Belinda M. S. and Carla S. W. (1999). Cardiovascular and renal benefits of dry bean and soybean intake. Am. J. Clin. Nutr., 70 (suppl): 464S-474S.

A.O.A.C.(2005). Association of Official Analytical Chemists. Official Methods of Analysis. $17^{\text {th }}$ Edition, Washington, DC., USA.

Asp N. G., Johansson C. G., Hallmer H. and Seljestron M. (1983). A rapid enzymatic assay of insoluble and soluble dietary fiber. J. Agric. Food Chem., 31: 476-479.

Bantle J. P., Wylie-Rosett J. and Albright A. L. (2006).Nutrition recommendations and interventions for diabetes: a position statement of the American Diabetes Association. Diabetes Care, 29: 21402157.

Barnes K. W.(1997). Trace metal determinations in fruits, juice and juice products using an axially viewed plasma. Atomic Spectroscopy, 18: 84-101.

Becker R., Wheeler E.L., Lorenz K.,Stafford A. E., Grosjean O. K., Bschart A. A. and Saunders R. M. (1981). A compositional study on amaranth grain. J. Food Sci., 46: 1175-1180.

Brownlee I. A.(2011). The physiological roles of dietary fiber.Food Hydrocolloids, 25:238250.

Champagne M., Garg A., Lutjohann D., Bergmann K., Grundy S. M. and Brinkley L. J. (2004). Benefical effects of high dietary fiber intake in glycemic response. J. Cereal Sci., 36 (1): 59-66.

Doweidar M. M., Abo-El Naga M. M. and Aseal M. A. (2010). Using untraditional sources of fiber to prepare chocolate cake. Bull. Fac. Agric. Cairo Univ., 61: 376-389.
Emperatriz P. D. (2005). Effect of enrichement with high content dietary fiber stabilized rice bran flour on chemical and functional properties of storage frozen pizzas. J. Food Enginer., 68 (1): 1-7.

$\mathrm{FAO} / \mathrm{WHO} / \mathrm{UNU}$ (2008). Proteins and amino acids in human nutrition. FAO/WHO/UNU Expert Consultation.World Health Organization, Tech. Rep. Ser.; No.935,p. 265.

Federal Register (1993). Food Labeling, General Provisions, Nutrition Labeling, State and Local Requirements and Exemption, Final Rules for 21 CFR part 1, (Jan., 6) 58: 2179.

Gomez K. A. and Gomez A. A. (1984). Statistical Procedure for Agricultural Research. John Wiley and Sons, Inc., USA.

Hafez H. A. (2004). Production and evaluation of some bakery products supplemented with soybean products. M.Sc. Thesis, Fac. Agric. Cairo Univ., Egypt.

Hamid A. A. and Luan Y. S. (2000). Functional properties of dietary fiber prepared from defatted rice bran. Food Chem., 68(1): 1519.

Hamid A. A., Sulaiman R. R., Osman A. and Saari N. (2007). Preliminary study of the chemical composition of rice milling fractions stabilized by microwave heating. J. Food Comp. Anal., 20: 627-637.

Hoogenkamp H. (2008). Rice bran isolate: the alternative for soy protein. Poultry Proc. Magazine, 4(2): 20-22.

Iqbal S., Bhanger M. I. and Anwar F. (2005). Antioxidant properties and components of some commercially available varieties of rice bran in Pakistan. Food Chem.,93(2): 265-272.

Jaime L., Molla E., Fernandez A., Martin M., Lopez, A. F. and Esteban R. (2002). Structural carbohydrates differences and potential source of dietary fiber of onion tissues. J. Agric. Food Chem., 50: 122128.

James C. S. (1995). Analytical Chemistry of Foods. Chap.6, General Food Studies, First Edition, The Alden Press, Oxford, UK.

Jiamyangyuen S., Srijesderuk V. and Harper W. J. (2005). Extraction of rice bran protein concentrate and its application in bread. Songklanakarin J. Sci. Tech., 27(1): 5564. 
Mahfouz S. A., El-Karamany A. M. and Soliman S. A. (2007). Chemical, technological and sensory evaluation of biscuit and cake made from wheat flour (72\% extraction), hull-less barley and chickpea flour blends. Egypt. J. Nutr., 4: 121-127.

Meilgaard M. C., Civille G. V. and Carr B. T. (2007). Sensory evaluation techniques, $14^{\text {th }}$ edition. CRC press, Boca Raton, FL, USA.

Miller E.L. (1967). Determination of the try ptophan content in feeding stuffs with Particular reference to cereals.J. SCI. food. Agric.18;381-386.

Mitchell H. H. and Block J. (1946). The correlation of amino acid composition of protein with their nutritive value. Nutr. Abst. and Rev., 16(2): 161-168.

Nielson M. H. (2002). The double challenge of cakes. Int. Food Ingre., 4: 73-74.

NRC National Research Council (2010). Recommended Dietary Allowances, 33 Edition, National Academy Press, Washington, DC., USA.

Philippi S. T. (2008). Piramide dos alimentos: fundamentos basicos da nutricao. Barueri, SP: Manole, pp.378.

Phillips G. O.(2011).An introduction: Evolution and finalization of the regulatory definition of dietary fibers.Food Hydrocolloids,25:139143.

Sharma H. R. and Chauhan G. S. (2002). Effects of stabilized rice bran: fenugreek blends on the quality of breads and cookies. J. Food Sci. Tech., 39(3): 225-233.

Siddiq M. M., Nasir R.; Ravi M. S., Butt K. D. and Harte J. B. (2009). Effect of defatted maize germ flour addition on the physical and sensory quality of wheat bread. Food Sci. Tech., 42: 464-470.

Singelton V. R., Orthifer R. and LamuelaRaventos R. M. (1999). Analysis of total phenols and other oxidation substances and antioxidants by means of Folin-Ciocalteu reagent. Methods Enzymol., 299: 152-178.

Smith, W. H. (1972). Biscuit Crackers and Cookies. Vol. 1, Applied Science Publishers, LTD. London, UK.

USDA (2013). United States Department of Agricultural, Economic and Statistics System. Official Report, Apr. 4, 2013.

Zoulias E. I., Oreopoulou V. and Tzia C. (2000). Effect of fat mimetics on physical, textural and sensory properties of cookies. Int. J. Food Proper., 3: 385-397.

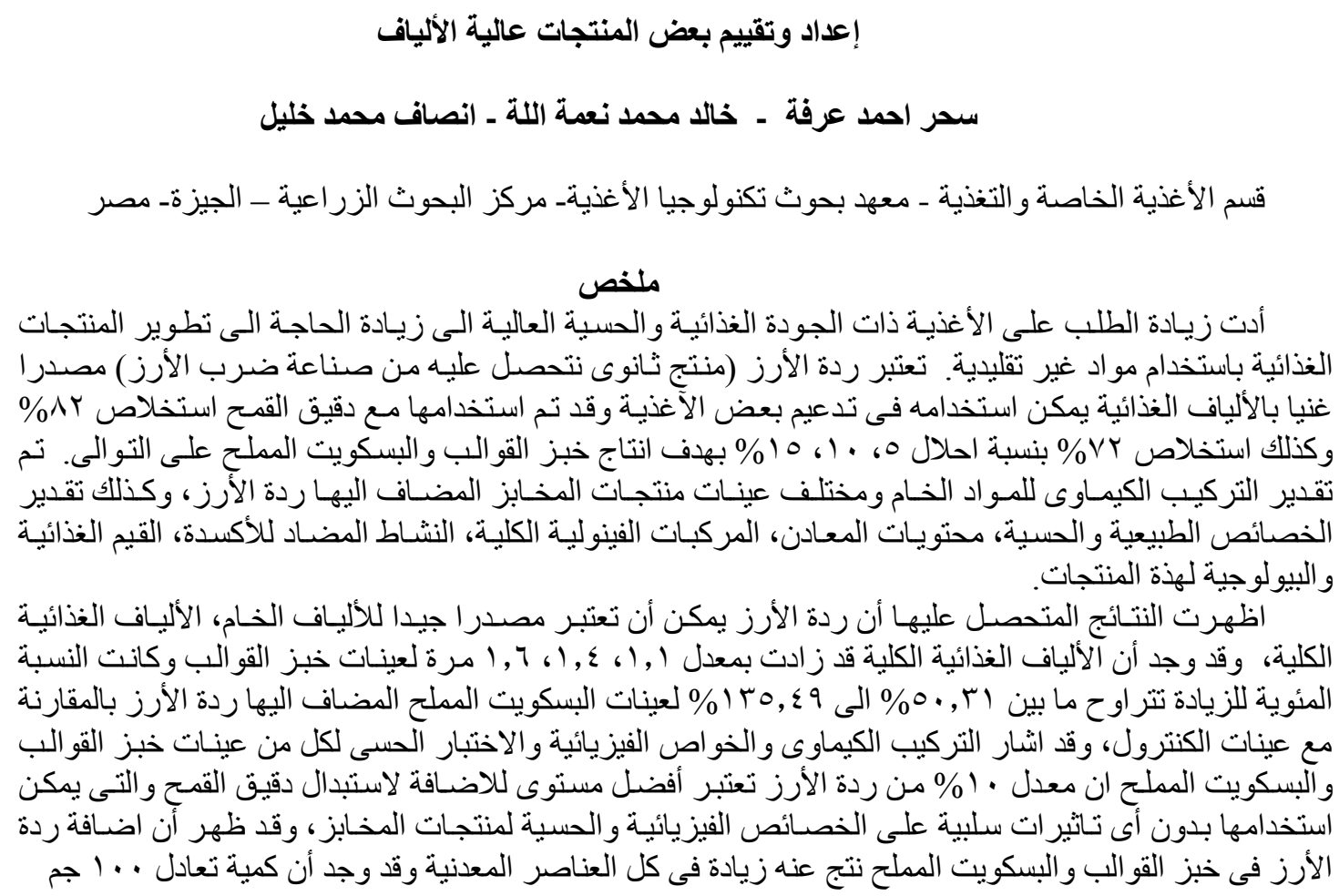




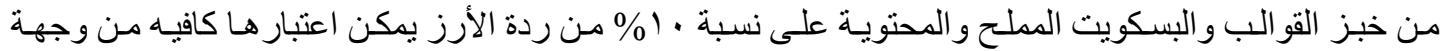

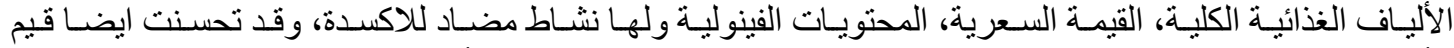

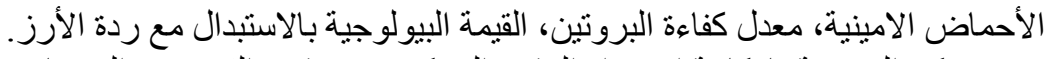

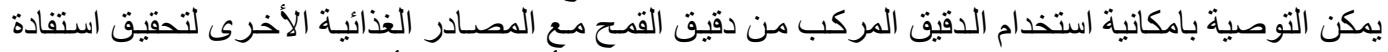

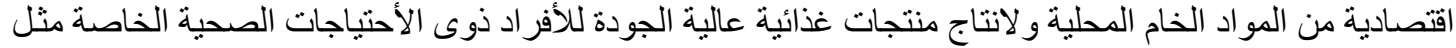

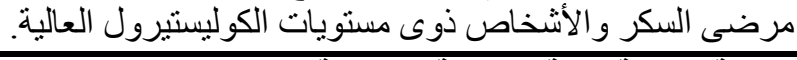

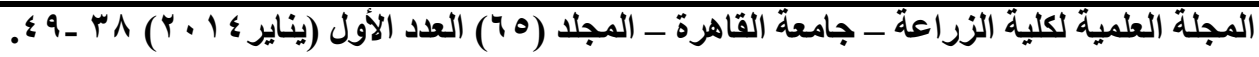

